PRACE NAUKOWE UNIWERSYTETU EKONOMICZNEGO WE WROCLAWIU

Badania marketingowe -

zmiany w metodologii i technikach badawczych

\title{
Marcin Gąsior
}

Politechnika Lubelska

e-mail:m.gasior@pollub.pl

WZORCE KORZYSTANIA

Z MEDIÓW SPOŁECZNOŚCIOWYCH

A ZAANGAŻOWANIE MEODYCH KONSUMENTÓW

W KOMUNIKACJĘ MARKETINGOWĄ

PRZEDSIĘBIORSTWA - ANALIZA ZMIAN

W LATACH 2013-2015

THE RELATIONSHIP BETWEEN
YOUNG CONSUMERS' PATTERNS OF SOCIAL MEDIA
USAGE AND THEIR WILLINGNESS
TO PARTICIPATE IN MARKETING COMMUNICATION
- COMPARISON BETWEEN 2013 AND 2015

DOI: $10.15611 / p n .2016 .459 .16$

JEL Classification: M30, M37

Streszczenie: Celem niniejszego artykułu jest porównanie wyników badania związku pomiędzy wzorcem korzystania przez konsumenta z mediów społecznościowych a czynnikami decydującymi o jego zaangażowaniu w komunikację marketingową przedsiębiorstwa, prowadzonego w latach 2013 oraz 2015. W celu uwidocznienia przytaczanych wzorców, w obu grupach badanych przeprowadzona została segmentacja użytkowników wg kryterium stosunku do różnych funkcji i aktywności podejmowanych w obrębie portalu społecznościowego, dla każdego zaś spośród tak wyodrębnionych segmentów wyznaczona została odrębna kombinacja czynników angażujących i zniechęcających do wirtualnej interakcji z przedsiębiorstwem. Umożliwiło to diagnozę potencjalnych zmian w sposobie korzystania $\mathrm{z}$ tego typu portali, z drugiej zaś strony ocenę różnic w oczekiwaniach odnośnie do procesów komunikacji marketingowej w nich zachodzących.

Słowa kluczowe: media społecznościowe, zachowanie konsumenta, komunikacja marketingowa.

Summary: The purpose of this article is to compare the results of two studies of the relationship between young consumers' patterns of social media usage and their willingness to participate in marketing communication, conducted in 2013 and 2015. In order to reveal aforementioned patterns, cluster analysis has been used, which made it possible to establish groups of participants with similar attitude towards different, possible activities one can undertake using social media. Subsequently, for each of those groups a different combination 
of factors that encourage to and discourage from involving in marketing communication processess has been identified. The comparison between 2013 and 2015 created an opportunity to evaluate possible changes in media users' behaviour and shifts in their expectations.

Keywords: social media, consumer behaviour, marketing comunication.

\section{Wstęp}

Media społecznościowe, rozumiane jako oparte na sieci Internet aplikacje i usługi, umożliwiające tworzenie i wymianę treści generowanych przez ich użytkowników [Kaplan, Haenlein 2010], na trwałe zadomowiły się w dzisiejszej rzeczywistości rynkowej, tworząc dogodną i efektywną platformę służącą zarówno budowie wirtualnej obecności przedsiębiorstwa, jak i prowadzeniu działań z obszaru komunikacji marketingowej. Wśród wspomnianych mediów największą popularnością, a co się z tym wiąże - także największym znaczeniem i uwagą [Weinberg, Pehlivan 2011] cieszą się serwisy społecznościowe - platformy elektroniczne, umożliwiające tworzenie sieci znajomych osób $\mathrm{w}$ celu wchodzenia $\mathrm{z}$ nimi w interakcje o charakterze prywatnym oraz zawodowym [Trusov, Bucklin, Pauwels 2009].

Literatura wymienia wiele przyczyn, dla których konsumenci są skłonni korzystać z portali społecznościowych. Wyróżnić można tutaj między innymi chęć do interakcji społecznej, poszukiwanie informacji (także dotyczącej przedsiębiorstw, produktów i handlu), chęć spędzenia wolnego czasu lub przyspieszenia jego upływu, zabawa i relaks oraz czerpanie przyjemności, dążenie do ekspresji i wyrażania swoich opinii, komunikację z innymi i dzielenie się z nimi informacjami, ale także śledzenie i gromadzenie wiedzy o innych ludziach - użytkownikach medium bądź portalu [Whiting, Williams 2013; Kietzmann i in. 2011; Lin, Lu 2011]. Znaczenie może mieć także dążenie do ucieczki przed rzeczywistością, szukanie inspiracji, ekspresja siebie, budowanie sieci powiązań czy też pragmatyczna chęć do pozostawania w kontakcie z dalszymi znajomymi [Heinonen 2011].

Duża ilość zastosowań, a także różnorodne motywy obecności konsumenta w portalu społecznościowym przekładają się w naturalny sposób na różne podejścia do jego wykorzystania, a także na zróżnicowanie oczekiwań i preferencji odnośnie do jego funkcjonalności (zob. np. [Pagani, Hofacker, Goldsmith 2011]). Prowadzone badania wskazują równocześnie istnienie znacznej liczby czynników decydujących o udziale konsumenta w komunikacji marketingowej przedsiębiorstwa, prowadzonej przy wykorzystaniu mediów społecznościowych (zob. np. [Taylor, Lewin, Strutton 2011]), dowodzą także różnic w ich znaczeniu wśród różnych grup potencjalnych odbiorców [Gąsior 2015].

Celem prezentowanego badania stała się powtórna ocena zdiagnozowanego uprzednio (zob. [Gąsior 2014]) związku pomiędzy wzorcem korzystania z mediów społecznościowych, rozumianym tutaj jako charakterystyczna dla danego użytkownika kombinacją wag przypisywanych kolejnym, możliwym celom wykorzystania 
portalu społecznościowego, a czynnikami decydującymi o zaangażowaniu w komunikację marketingową prowadzoną tym kanałem. Dzięki porównaniu dwóch grup respondentów przebadanych w odstępie dwóch lat, możliwe stało się sformułowanie wniosków odnośnie do zarówno zmian w sposobie korzystania z mediów społecznościowych, jak i czynników zachęcających i zniechęcających do odbioru i uczestnictwa w procesach komunikacji.

\section{Założenia badawcze}

Materiał empiryczny niezbędny do oceny potencjalnego związku pomiędzy wzorcem korzystania przez młodego konsumenta z mediów społecznościowych a jego skłonnością do zaangażowania $\mathrm{w}$ działania $\mathrm{z}$ obszaru komunikacji marketingowej oraz czynnikami skłonność tę budującymi pozyskany został w drodze dwóch badań ankietowych, prowadzonych techniką on-line. Jako instrument badawczy w obu przypadkach wykorzystane zostały interaktywne kwestionariusze, obejmujące 57 zmiennych w roku 2013, zaś w roku 2015 - 62 zmienne. Dotyczyły one między innymi własnej oceny wagi i znaczenia kolejnych działań możliwych do podjęcia przez użytkownika w obrębie portalu społecznościowego, częstotliwości odwiedzania tego rodzaju portali, jak również postrzegania czynników zachęcających i zniechęcających do zaangażowania $\mathrm{w}$ prowadzone $\mathrm{w}$ ich obrębie działania $\mathrm{z}$ obszaru komunikacji marketingowej. Badane zmienne, z wyjątkiem tych o typowo nominalnym lub porządkowym charakterze, mierzone były przy wykorzystaniu dziesięciostopniowych skal semantycznych, w których oceny niskie oznaczały niewielkie znaczenie bądź negatywny odbiór danej zmiennej, natomiast wysokie - jego dużą rolę bądź pozytywne postrzeganie.

W badaniach wzięło udział odpowiednio 484 (edycja 2013) oraz 382 (edycja 2015) respondentów dobranych w sposób kwotowy spośród wszystkich użytkowników sieci Internet w wieku od 18 do 30 lat, deklarujących korzystanie z portali społecznościowych. Kwoty zdefiniowane zostały w oparciu o dostępne dane Głównego Urzędu Statystycznego w taki sposób, aby struktura próby odzwierciedlała strukturę badanej populacji z punktu widzenia wielkości miejsca zamieszkania, przedziału wiekowego oraz płci respondenta.

Ocena związku pomiędzy wzorcem korzystania z mediów społecznościowych, a zaangażowaniem badanego w procesy komunikacji marketingowej prowadzonej w ich obrębie przebiegała dwuetapowo. W pierwszej kolejności przy wykorzystaniu analizy skupień [Rand 1971] wyodrębniono, oddzielnie w przypadku każdego z etapów badania, spójne zbiory respondentów o zbliżonym wzorcu korzystania z portalu społecznościowego, rozumianym w tym przypadku jako podobna kombinacja ocen znaczenia działań możliwych do podjęcia w tego rodzaju mediach. Oceniane przez respondentów aktywności (16 zmiennych) obejmowały udostępnianie treści (publikowanie postów, dzielenie się zdjęciami i filmami, rekomendowanie firm i marek, polecanie książek i filmów, polecanie innych treści znalezionych $w$ Internecie), wy- 
szukiwanie i polecanie wydarzeń, konsumowanie treści stworzonej bądź opublikowanej przez innych (ogladanie treści znalezionej przez innych w Internecie, śledzenie wpisów znajomych, ogladanie zdjęć znajomych), interakcje $\mathrm{z}$ innymi użytkownikami (komentowanie postów, komentowanie zdjęć, rozmowy w czasie rzeczywistym - czat $i$ wiadomości), granie w gry dostępne na portalu oraz interakcje z treściami komercyjnymi (śledzenie fanpage'y firm, interakcje z fanpage'ami, udziat $w$ organizowanych konkursach i promocjach). Należy przy tym dodać, iż na pozyskanym materiale badawczym przeprowadzona została analiza czynnikowa, mająca za zadanie redukcję ilości zmiennych opisujących stosunek do badanych aktywności, która nie doprowadziła jednakże do satysfakcjonujących rezultatów, stąd też jako kryteria segmentacji przyjęto oceny wszystkich przedstawionych aktywności.

Sama analiza skupień przeprowadzona została w dwóch krokach. W pierwszej kolejności wykorzystana została aglomeracja przypadków (kwadrat odległości euklidesowych, metoda Warda), której zadaniem było wstępne określenie ilości skupień, następnie zaś, przy wykorzystaniu algorytmu EM (zob. [Celeux, Govaert 1992; McIachlan, Krishnan 1996; McQueen 1967]), utworzone zostały właściwe zbiory respondentów.

Dendrogramy obrazujące przebieg aglomeracji przypadków wskazały na zasadność stworzenia trzech lub sześciu skupień dla grupy badanych w 2013 roku oraz dwóch, trzech lub sześciu skupień w grupie respondentów z roku 2015. W celu ostatecznej oceny optymalnej ilości segmentów wykorzystany został ponadto V-krotny sprawdzian krzyżowy [Witten, Frank 2000]. Przy założeniu domyślnego minimalnego poziomu procentowego spadku funkcji błędu (definiowanej jako średnia odległości przypadków od centrów skupień), równego $5 \%$, wskazał on w obu grupach respondentów jako optymalną liczbę trzech segmentów. Dodatkowo, dla obu zbiorów danych obliczono wartości indeksu sylwetkowego oraz indeksu C Huberta-Levina, które, w zależności od zbioru i indeksu, wskazywały zasadność wyodrębnienia 3 lub 4 klastrów. W celu zapewnienia porównywalności oraz uproszczenia oceny różnic i podobieństw w obu przypadkach wyodrębniono i poddano analizie trzy skupienia.

Drugim etapem prowadzonej oceny stało się natomiast obliczenie w tak zdefiniowanych skupieniach średnich ocen znaczenia kolejnych czynników zachęcających oraz zniechęcających badanego do zaangażowania w procesy komunikacji marketingowej, a także wartości średnich dwóch zmiennych wyrażających jego ogólny, subiektywnie rozumiany, stosunek do tego rodzaju działan - postrzeganego sensu prowadzenia komunikacji oraz własnej skłonności do zaangażowania się w komunikację.

Na koniec należy zastrzec, że zarówno brak reprezentatywności obu prób, jak również fakt, iż w obu częściach badania uczestniczyły różne grupy respondentów, stanowią dość istotną przeszkodę dla porównywalności wyników z obu okresów. Niemniej jednak, ponieważ nie istnieje możliwość przeprowadzenia doboru losowego w tak zdefiniowanej populacji (brak operatu losowania), zaś rekrutacja tych samych respondentów byłaby - z powodu wielkości grupy oraz dużego odstęp czasowego między etapami badania - niezwykle kłopotliwa z organizacyjnego punktu 
widzenia, porównania między okresami zostaną, w ograniczonym zakresie, przeprowadzone, zwłaszcza że wyodrębnione grupy są dość ogólne i możliwe do zaobserwowania $\mathrm{w}$ obu analizowanych okresach.

\section{Wzorce korzystania z mediów społecznościowych}

W myśl przedstawionych uprzednio założeń w obu badanych grupach wyodrębnione zostały po trzy skupienia, łączące respondentów wykazujących zbliżony stosunek do kolejnych działań możliwych do podjęcia w obrębie portalu społecznościowego.

Jak można było się spodziewać, każda z segmentacji wykazała istnienie dwóch grup o skrajnych poglądach na korzystanie z tego typu serwisów - grupy entuzjastów oraz grupy sceptyków, jak również skupienia respondentów wykazujących opinie pośrednie, doceniających i wyrażających zainteresowanie częścią spośród możliwych aktywności, marginalizujących zaś pozostałe.

W przypadku badanych w roku 2013 (rys. 1) pierwsza z wyodrębnionych grup, grupa entuzjastów (S3) zadeklarowała wysokie znaczenie wszystkich możliwych aktywności z wyjątkiem gier na portalu, które zostały ocenione bardzo nisko (ocena średnia 3,21 przy dziesięciostopniowej skali pomiaru) oraz interakcji z treściami o charakterze komercyjnym (udział w konkursach, aktywności na fanpage'ach, które

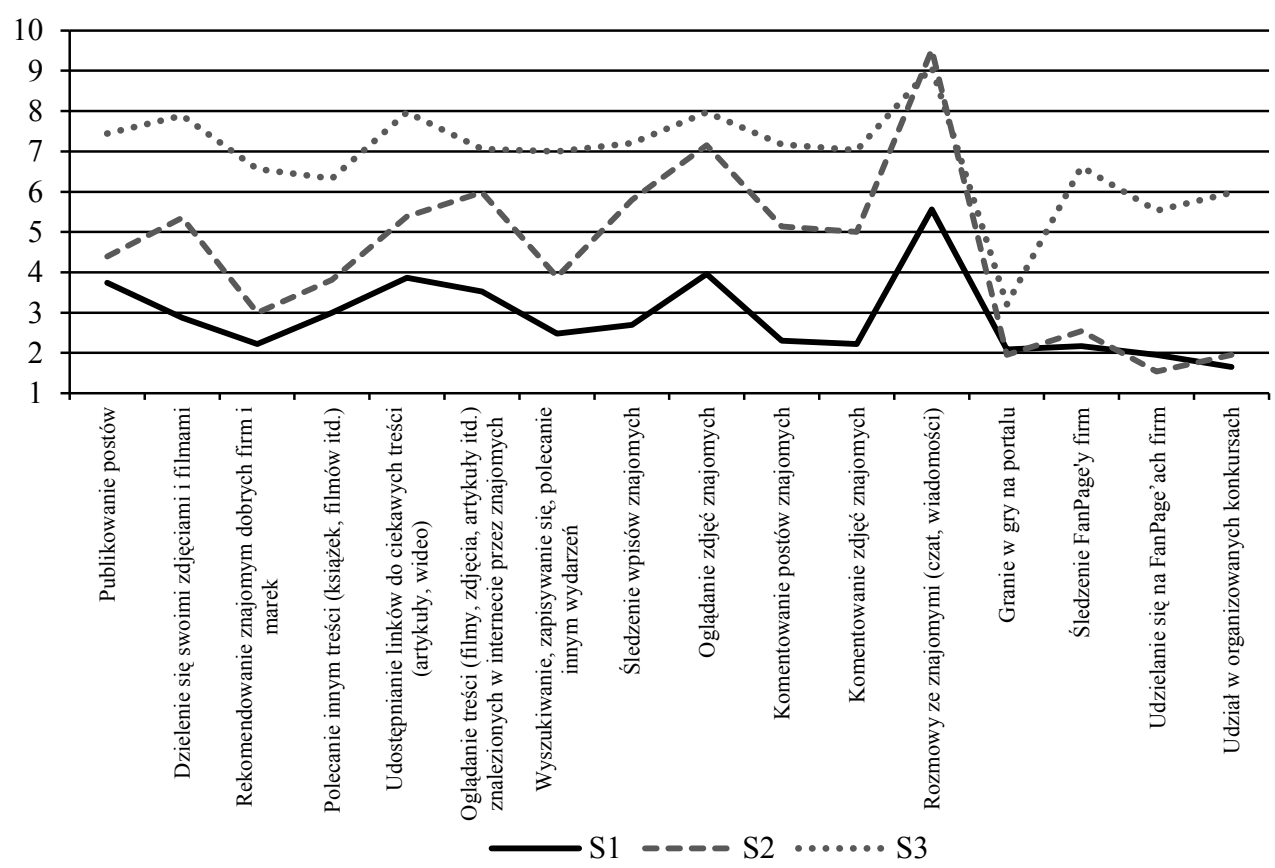

Rys. 1. Istotność możliwych aktywności w kolejnych wyodrębnionych segmentach - rok 2013

Źródło: opracowanie własne. 
uzyskały przeciętny poziom ocen (z przedziału 5,5-6,6). Przeciwieństwo tej grupy - sceptycy (S1) - nie przykładają większej wagi do kolejnych, możliwych aktywności; większość możliwych działań uzyskało średnią ocen poniżej wartości 4.0. W grupie tej jedyne funkcje portalu społecznościowego, mające wymierne, chociaż nadal niewielkie znaczenie, dotyczą interakcji z osobami znajomymi - bezpośredniej komunikacji $(5,57)$, oglądania zamieszczanych przez nich zdjęć $(3,96)$, a także udostępniania im treści własnych $(3,74)$ oraz znalezionych w sieci $(3,87)$.

Ostatnia wyodrębniona grupa (S2) wykazuje dość neutralne podejście do większości badanych aktywności, przy czym podobnie jak w przypadku grupy ,sceptyków", także w tym zbiorze interakcje związane z treścią komercyjną ocenione zostały wyraźnie negatywnie. Cechą charakterystyczną tej grupy jest równocześnie dość wysoka ocena działań związanych z odbiorem treści tworzonych bądź publikowanych przez innych użytkowników - dotyczy to w szczególności bezpośredniej komunikacji ze znajomymi (9,53), oglądania zdjęć znajomych $(7,15)$, śledzenie ich postów $(5,80)$ oraz oglądania zamieszczonych przez nich treści $(5,98)$, przy mniejszej, chociaż do pewnego stopnia widocznej skłonności do dzielenia się własnymi opiniami (oglądaniem komentowanie) oraz materiałami (udostępnianie linków, udostępnianie zdjęć i filmów, publikowanie postów) - stąd też grupę tę można określić mianem społecznych obserwatorów (zob. także [Gąsior 2014]).

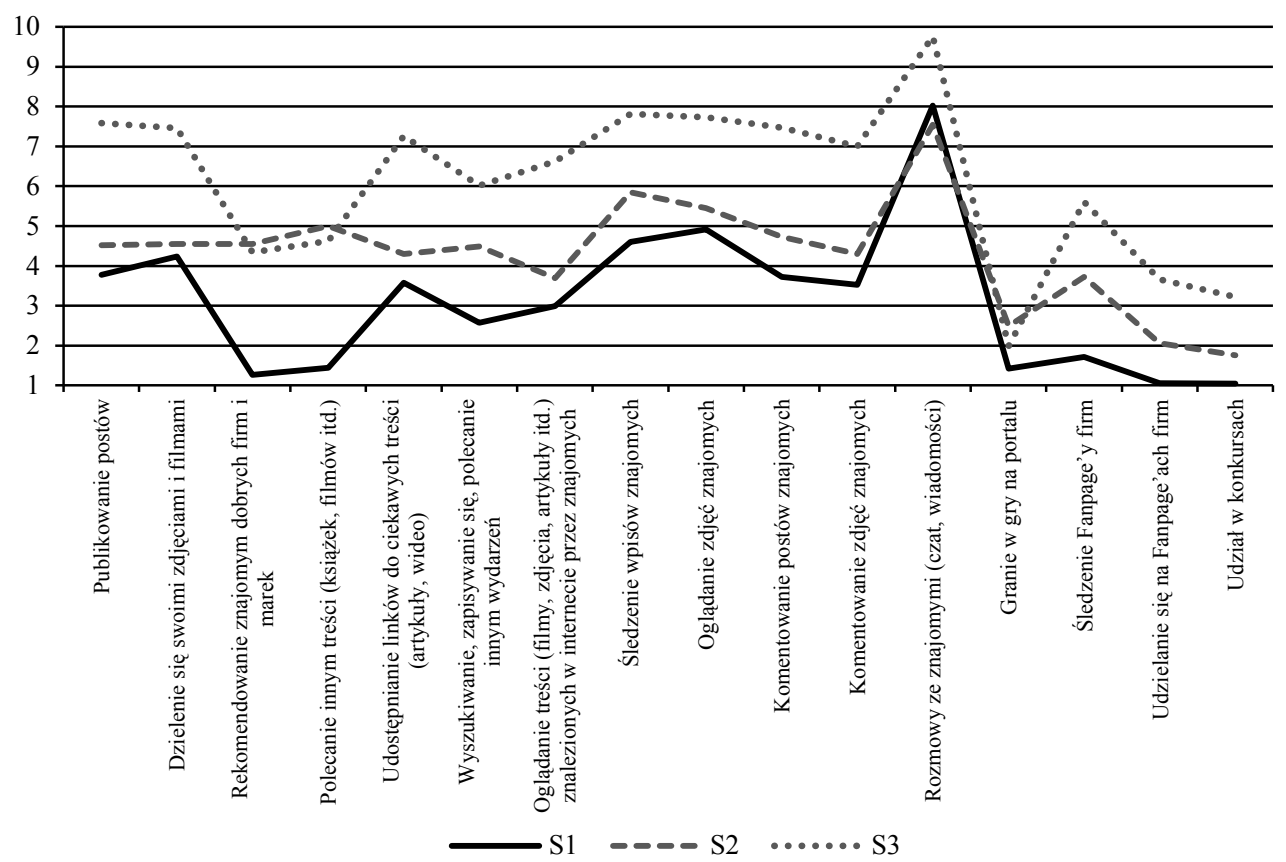

Rys. 2. Istotność możliwych aktywności w kolejnych wyodrębnionych segmentach - rok 2015

Źródło: opracowanie własne. 
Zbliżony, chociaż nie identyczny, układ preferencji użytkowników zauważyć można w grupie respondentów przebadanych w 2015 roku (rys. 2). Także tutaj zaobserwować można grupę osób o nastawieniu względnie sceptycznym (S1), która w przeciwieństwie do analogicznej grupy z badania w roku 2013 wykazuje nieco bardziej zróżnicowany stosunek do kolejnych możliwych aktywności. Podobnie jak uprzednio, grupa ta marginalizuje znaczenie odbioru treści komercyjnych, równocześnie dostrzega wagę bezpośredniej komunikacji ze znajomymi (ocena średnia 8,03 ) oraz, w pewnym zakresie, innego rodzaju interakcji społecznych - dotyczących głównie odbioru i publikacji własnych treści (śledzenie wpisów, oglądanie zdjęć, publikowanie postów, dzielenie się swoimi zdjęciami), ale już nie treści zewnętrznych. $Z$ uwagi na to ten zbiór respondentów można określić mianem społecznych sceptyków.

Przeciwieństwem tej grupy jest zbiór osób o najbardziej entuzjastycznym podejściu do kolejnych możliwych aktywności (S3), chociaż należy w tym punkcie zwrócić uwagę, iż oceny średnie kolejnych możliwych działań są wyraźnie niższe niż w analogicznej grupie badanych w 2013 roku. W szczególności wyraźny spadek zainteresowania zaobserwować można w obszarze aktywnego udziału w działaniach komercyjnych (udzielanie się na fanpage'ach, udział w konkursach), a także, co dość interesujące, $\mathrm{w}$ zakresie polecania innym treści zewnętrznych (książki, filmy) oraz marek i firm.

Ostatnia wyodrębniona grupa (S2) wydaje się mieć najbardziej zrównoważony, chociaż względnie sceptyczny (większość ocen poniżej wartości 5,50, stanowiącej połowę zastosowanej skali), stosunek do różnych aktywności podejmowanych na portalach społecznościowych. Respondenci z tej grupy, podobnie jak reszta badanych, przypisują największą wagę możliwości komunikacji w czasie rzeczywistym $(7,55)$, równocześnie dość nisko oceniają interakcję z treściami komercyjnymi. W przypadku pozostałych możliwych działań oceny średnie są względnie wyrównane, badani ci wykazują jednakże nieco większe znaczenie biernej obserwacji innych osób (śledzenie wpisów znajomych, oglądanie zdjęć znajomych). Co interesujące, w największym stopniu spośród wszystkich grup są skłonni do udzielania rekomendacji w zakresie firm, marek, jak również innych treści - literatury i filmu. Badanych tych można $\mathrm{w}$ związku z tym określić mianem zrównoważonych użytkowników.

\section{Czynniki decydujące o zaangażowaniu w komunikację marketingową}

Kolejną częścią prowadzonego badania stała się ocena znaczenia kolejnych czynników zachęcających (tabela 1) oraz zniechęcających (tabela 2) użytkownika do zaangażowania w procesy komunikacji marketingowej, prowadzone przy wykorzystaniu mediów i portali społecznościowych. Średnie ocen kolejnych badanych czynników zostały obliczone dla każdego badanego okresu łącznie oraz przy rozdzieleniu respondentów wg skupienia, do którego zostali przyporządkowani. 
Porównując oceny ogólne, łączne dla wszystkich respondentów, w pierwszej kolejności należy zwrócić uwagę, iż w obu okresach kluczową rolę wydają się odgrywać czynniki wiążące się z korzyścią materialną - w roku 2013 była to możliwość uzyskania zniżki $(7,34)$, możliwość otrzymania produktu $(7,23)$, gadżetów i upominków $(6,53)$ oraz udostępnianie informacji o promocjach i zniżkach $(6,78)$. W drugim okresie badania zaobserwować można niewielkie zmiany w hierarchii, jako czynnik najistotniejszy wskazane zostały informacje o promocjach i zniżkach $(6,38)$, następnie zaś publikowanie ciekawych treści - innych niż reklamowe $(6,20)$, możliwości uzyskania zniżki $(6,15)$ i otrzymania produktu $(5,71)$.

Tabela 1. Oceny średnie czynników zachęcających do zaangażowania w komunikację marketingową

\begin{tabular}{|l|c|c|c|c|c|c|c|c|}
\hline \multirow{2}{*}{\multicolumn{1}{|c|}{ Czynnik }} & \multicolumn{4}{|c|}{2013} & \multicolumn{5}{c|}{2015} \\
\cline { 2 - 9 } & S1 & S2 & S3 & Og. & S1 & S2 & S3 & Og. \\
\hline Możliwość uzyskania zniżki & 5,65 & 7,42 & 8,35 & 7,34 & 4,63 & 6,32 & 7,37 & 6,15 \\
\hline Możliwość otrzymania produktu & 5,83 & 7,19 & 8,26 & 7,23 & 4,54 & 5,90 & 6,59 & 5,71 \\
\hline Udostępnianie inf. o promocjach i zniżkach & 5,04 & 6,86 & 7,79 & 6,78 & 4,94 & 6,61 & 7,52 & 6,38 \\
\hline Możliwość otrzymania gratisów i upominków & 4,78 & 6,27 & 8,18 & 6,53 & 3,55 & 5,10 & 6,24 & 5,02 \\
\hline Publikowanie inf. o nowościach w ofercie & 4,96 & 6,37 & 7,50 & 6,42 & 4,41 & 6,13 & 6,67 & 5,70 \\
\hline Przywiązanie lub sympatia do marki & 5,09 & 5,78 & 6,59 & 5,88 & 3,90 & 5,74 & 6,67 & 5,45 \\
\hline Ciekawe treści, inne niż reklamy & 5,13 & 5,54 & 6,97 & 5,88 & 4,79 & 6,16 & 7,35 & 6,20 \\
\hline Publikowanie interesujących reklam & 3,48 & 5,58 & 6,85 & 5,53 & 3,63 & 4,52 & 5,59 & 4,66 \\
\hline Udział firmy w dyskusjach na profilu & 4,13 & 5,24 & 6,97 & 5,53 & 3,42 & 5,80 & 6,31 & 5,10 \\
\hline Możliwość udziału w konkursach & 4,09 & 4,85 & 7,59 & 5,50 & 2,01 & 3,35 & 4,65 & 3,42 \\
\hline Możliwość wyrażania opinii o produktach & 4,04 & 5,05 & 7,15 & 5,47 & 3,73 & 5,87 & 6,13 & 5,17 \\
\hline Umieszczanie informacji o wydarzeniach & 3,57 & 5,07 & 6,76 & 5,27 & 2,80 & 4,48 & 5,46 & 4,27 \\
\hline Możliwość komunikacji z innymi & 3,96 & 5,14 & 6,29 & 5,24 & 3,40 & 5,32 & 6,18 & 4,98 \\
\hline Przyjazna, interesująca społecznośćc & 3,74 & 4,44 & 6,85 & 5,01 & 3,46 & 5,52 & 7,35 & 5,58 \\
\hline Częste publikowanie treści na fanpage’u & 3,30 & 3,73 & 6,35 & 4,41 & 3,48 & 3,99 & 6,25 & 4,81 \\
\hline Pojawianie się informacji ,z życia” firmy & 2,65 & 3,95 & 5,62 & 4,18 & 3,21 & 5,23 & 5,58 & 4,61 \\
\hline Skłonność do zaangażowania w komunikację & 5,38 & 5,73 & 6,78 & 5,99 & 5,22 & 5,36 & 6,62 & 5,88 \\
\hline Postrzegana zasadność komunikacji & 6,08 & 6,91 & 7,70 & 6,99 & 5,80 & 5,71 & 7,14 & 6,41 \\
\hline
\end{tabular}

Źródło: opracowanie własne. S1, S2, S3 oznaczają kolejne skupienia, Og. - respondentów łącznie.

Pewne różnice zaobserwować można także przy porównaniu kolejnych wyodrębnionych grup. Analizując opinie osób najbardziej sceptycznie nastawionych do mediów społecznościowych (S1), zauważyć można, iż w pierwszym z omawianych okresów badani ci wskazywali na duże znaczenie możliwości otrzymania produktu $(5,83)$, uzyskania zniżki $(5,65)$, informacji o promocjach $(5,04)$, ale także na dostępność ciekawych treści $(5,13)$ oraz przywiązanie do marki $(5,09)$; w drugim z analizowanych okresów wśród sceptyków największą istotność przypisano udostępnianiu informacji o promocjach i zniżkach $(4,94)$, ciekawym treściom multimedialnym, innym niż reklamy $(4,79)$, dopiero w dalszej kolejności na możliwości uzyskania 
zniżki $(4,63)$ oraz produktu $(4,54)$. Istotnej wcześniej sympatii do marki przypisano o wiele mniejsze znaczenie $(3,90)$.

Interesujących informacji dostarcza także porównanie obu grup najbardziej entuzjastycznie nastawionych do mediów społecznościowych (S3). W badaniu z 2013 roku grupa ta wykazywała kompletną orientację na bodźce materialne, wskazując jako najistotniejsze: możliwość uzyskania zniżki $(8,35)$, otrzymania produktu $(8,26)$, gadżetów i upominków $(8,48)$, otrzymania informacji o promocjach $(7,79)$ oraz udziału w konkursach $(7,59)$, podczas gdy analogiczna grupa wyodrębniona w 2015 roku, oprócz możliwości uzyskania informacji o promocjach $(7,52)$ oraz samej zniżki $(7,37)$, jako bardzo zachęcające wskazała także istnienie interesującej społeczności skupionej wobec marki $(7,35)$, przywiązanie do tej marki $(6,67)$ oraz dostępność interesujących treści niebędących reklamami $(7,35)$.

Ostatnie dwie grupy, społecznych obserwatorów oraz zrównoważonych użytkowników (S2), pomimo różnic w samym stosunku do mediów społecznościowych wykazały dość zbieżny stosunek do czynników zachęcających. W obu przypadkach największa waga przypisywana była czynnikom materialnym, niemniej jednak w przypadku pierwszej z omawianych grup sama korzyść miała większe znaczenie niż informacja o możliwości jej uzyskania, podczas gdy w drugiej grupie badanych pojawia się odniesienie do treści innych niż reklamy, zaś czynniki związane z informacjami o korzyściach i ofercie ocenione były jako bardziej istotne niż samo otrzymanie korzyści.

Tabela 2. Oceny średnie czynników zniechęcających do zaangażowania w komunikację marketingową

\begin{tabular}{|l|c|c|c|c|c|c|c|c|}
\hline \multirow{2}{*}{ Czynnik } & \multicolumn{4}{|c|}{2013} & \multicolumn{5}{c|}{2015} \\
\cline { 2 - 10 } & S1 & S2 & S3 & Og. & S1 & S2 & S3 & Og. \\
\hline Agresywność prowadzonej komunikacji & 6,87 & 7,79 & 7,66 & 7,54 & 7,51 & 8,09 & 8,45 & 8,03 \\
\hline Brak popularności firmy wśród znajomych & 3,39 & 4,74 & 3,69 & 3,94 & 3,19 & 3,25 & 3,51 & 3,34 \\
\hline Brak reakcji na wypowiedzi użytkowników & 7,43 & 7,82 & 8,18 & 7,92 & 6,04 & 7,44 & 7,87 & 7,09 \\
\hline Nakłanianie do zakupu produktów & 6,91 & 6,94 & 7,29 & 7,11 & 6,04 & 6,71 & 7,51 & 6,81 \\
\hline Negatywne doświadczenia z produktami firmy & 7,43 & 7,97 & 8,93 & 8,34 & 7,10 & 8,03 & 8,33 & 7,80 \\
\hline Negatywne opinie innych użytkowników & 6,96 & 7,52 & 7,68 & 7,49 & 5,79 & 6,16 & 7,30 & 6,53 \\
\hline Nieciekawe treści (zdjęcia, wpisy itd.) & 6,83 & 7,03 & 7,31 & 7,13 & 5,42 & 6,13 & 7,29 & 6,37 \\
\hline Nieregularne albo rzadkie publikowanie treści & 4,70 & 6,84 & 5,69 & 5,80 & 4,46 & 6,03 & 6,30 & 5,55 \\
\hline Niesympatyczna społecznośćc & 5,70 & 7,30 & 6,98 & 6,81 & 5,92 & 7,55 & 7,57 & 6,92 \\
\hline Nieuprzejmość osób obsługujących profil & 7,87 & 7,88 & 8,52 & 8,19 & 7,21 & 8,31 & 8,75 & 8,08 \\
\hline Sztuczność prowadzonych działań & 7,00 & 7,21 & 7,95 & 7,54 & 6,15 & 6,91 & 8,04 & 7,12 \\
\hline
\end{tabular}

Źródło: opracowanie własne. S1, S2, S3 oznaczają kolejne skupienia, Og. - respondentów łącznie

Mniejsze różnice zarówno między badanymi okresami, jak i wśród wyodrębnionych grup zauważyć można w przypadku czynników zniechęcających do zaangażowania w komunikację marketingową (tab. 2). W ocenie ogólnej w obu przypadkach dominują czynniki związane z jakością interakcji (nieuprzejmość pracowników, agresywność komunikacji, sztuczność działań, brak reakcji na wypowiedzi klien- 
tów) oraz negatywne doświadczenia z produktami firmy, podczas gdy czynniki związane z jakością samej udostępnianej treści wydają się mieć mniejsze znaczenie.

Wśród osób o sceptycznym podejściu najważniejszą różnicą jest wzrost znaczenia agresywności prowadzonych działań, które to znaczenie w roku 2013 nie było traktowane jako istotne, natomiast w roku 2015 znalazło się na szczycie hierarchii czynników. Zbliżona sytuacja ma miejsce w zbiorach osób o podejściu najbardziej entuzjastycznym. Tutaj także nastąpił wzrost znaczenia agresywności prowadzonej komunikacji, ale także sztuczności prowadzonych działań, oraz niewielki spadek znaczenia negatywnego doświadczenia z produktami firmy oraz braku reakcji na wypowiedzi klientów. W obu grupach respondentów kluczowe znaczenie ma brak uprzejmości personelu obsługującego komunikację.

Porównanie ostatnich dwóch grup o pośrednim stosunku do mediów społecznościowych (S2) ponownie wykazuje istnienie pewnych różnic. Dotyczą one zmiany znaczenia czynników związanych z przebiegiem interakcji (nieuprzejmość, brak reakcji, sztuczność), które są bardziej istotne w grupie społecznych obserwatorów (2013), co też wydaje się zgodne z jej charakterem, podczas gdy w grupie zrównoważonych użytkowników większy nacisk kładzie się na samą treść przekazu (nieuprzejmość pracowników, agresywność komunikacji, nieprzyjemna społeczność). W drugiej grupie zaobserwować można także mniejsze znaczenie negatywnych doświadczeń z produktami.

\section{Podsumowanie}

Przeprowadzone badanie, pomimo wskazywanych uprzednio problemów z porównywalnością wyników, prowadzi do dość interesujących wniosków odnośnie do samego korzystania z mediów społecznościowych, ale także zmian, które można zaobserwować w stosunku odbiorców zarówno do samego medium, jak i do działań prowadzonych w jego obrębie.

W pierwszej kolejności warto podkreślić, iż pozyskane wyniki po raz kolejny potwierdzają tezę, że użytkownicy nie są tacy sami, tym samym także oczekują różnych kombinacji działań z obszaru komunikacji marketingowych oraz korzyści wynikających zarówno z odbioru tych działań, jak i własnego zaangażowania w interakcje. Analizując przedstawione wcześniej wzorce korzystania z mediów społecznościowych, warto zwrócić uwagę na fakt zaniku obserwowanej w pierwszym etapie badania grupy typowych ,sceptyków” na rzecz powstania grupy sceptyków „uspołecznionych". Może wiązać się to z ewolucją podejścia do obecności w portalach społecznościowych, z ,posiadania konta dla samego posiadania” na korzyść posiadania go i wykorzystywania, bądź też wynikać z całkowitej rezygnacji typowych sceptyków z korzystania z portali społecznościowych.

Wyraźne zmiany zauważyć można także w stosunku do czynników zachęcających i zniechęcających do zaangażowania w komunikację. Wśród tych pierwszych, nastąpiło odejście od bodźców materialnych na rzecz treści i informacji o korzy- 
ściach, co być możne jest związane ze spadkiem zaufania do komunikacji prowadzonej tym kanałem bądź też wzrostem dbałości o własną prywatność - ponieważ otrzymanie materialnej gratyfikacji zawsze wiąże się $\mathrm{z}$ pewną formą czynnego zaangażowania (a więc wyjścia poza rolę anonimowego obserwatora), czego nie można powiedzieć o pasywnym odbiorze informacji. Warto jednakże zauważyć, że zmiany te wpisują się we wskazywane w literaturze znaczenie jakości treści dla odbioru komunikacji (zob. np. [Baird, Parasnis 2011]). Obserwowane pragmatyczne, zorientowane na korzyść podejście jest tutaj raczej cechą rodzimych konsumentów, a nie dominującą prawidłowością.

Pozyskane wyniki dowodzą także spadku skłonności do zaangażowania w procesy komunikacji, o czym świadczą zarówno niższe oceny średnie kolejnych czynników decydujących o zaangażowaniu, jak również odpowiedzi na bezpośrednie pytanie dotyczące tejże skłonności, a także postrzeganego sensu tego typu komunikacji (tabela 1). Wymienione zmiany znalazły swoje odzwierciedlenie także w opiniach badanych zgromadzonych w kolejnych wyodrębnionych grupach. Obejmują one w szczególności wzrost znaczenia treści, związku z marką oraz roli społeczności skupionej wokół marki wśród osób najchętniej korzystających z mediów społecznościowych, a równocześnie spadek roli czynników typowo materialnych na rzecz treści i informacji wśród osób najbardziej sceptycznych.

\section{Literatura}

Baird C., Parasnis G., 2011, From social media to social customer relationship management, Strategy \& Leadership, 39(5), 30-37.

Celeux G., Govaert G., 1992, A classification EM algorithm for clustering and two stochastic versions, Computational Statistics \& Data Analysis, vol. 14(3), s. 315-332.

Gąsior M., 2014, Wpływ wzorców korzystania z mediów społecznościowych w grupie młodych konsumentów na zaangażowanie w komunikację marketingowa przedsiębiorstwa, Marketing i Rynek, 11 (CD), s. 367-373.

Gąsior M., 2015, Strukturalna ocena przyczyn zaangażowania młodego konsumenta w komunikacje marketingowa w mediach spolecznościowych, [w:] Rzemieniak M., Maciaszczyk M. (red.), Wspótczesny konsument i organizacja w świetle nowych trendów rynkowych, Wydawnictwo Państwowej Wyższej Szkoły Zawodowej w Tarnobrzegu, Tarnobrzeg, s. 89-102.

Heinonen K., 2011, Consumer activity in social media: Managerial approaches to consumers' social media behavior, Journal of Consumer Behaviour, 10, s. 356-364.

Kaplan A.M., Haenlein M., 2010, Users of the world, unite! The challenges and opportunities of Social Media, Business Horizons, vol. 53, issue 1, January-February, s. 59-68.

Kietzmann J.H., Hermkens K., McCarthy I.P., Silvestre B.S., 2011, Social media? Get serious! Understanding the functional building blocks of social media, Business Horizons, vol. 54, issue 3, MayJune, s. 241-251.

Lin Kuan-Yu, Lu Hsi-Peng, 2011, Why people use social networking sites: An empirical study integrating network externalities and motivation theory, Computers in Human Behavior, vol. 27, issue 3, May, s. 1152-1161.

McIachlan G., Krishnan T., 1996, The EM Algorithm and Extensions, Wiley-Interscience. 
MacQueen J.B., 1967, Some Methods for classification and Analysis of Multivariate Observations. Proceedings of 5-th Berkeley Symposium on Mathematical Statistics and Probability, University of California Press, Berkeley, s. 281-297.

Pagani M., Hofacker Ch., Goldsmith R., 2011, The influence of personality on active and passive use of social networking sites, Psychology \& Marketing, vol. 28 (5), s. 441-456.

Rand W., 1971, Objective Criteria for the Evaluation of Clustering Methods, Journal of the American Statistical Association, vol. 66(336), s. 846-850.

Taylor D., Lewin J., Strutton D., 2011, Friends, Fans, and Followers: Do Ads Work on Social Networks? How Gender and Age Shape Receptivity, Journal of Advertising Research, vol. 51(1), s. 258-275.

Trusov M., Bucklin R., Pauwels K., 2009, Effects of Word-of-Mouth Versus Traditional Marketing: Findings from an Internet Social Networking Site, Journal of Marketing, vol. 73(5), s. 90-102.

Weinberg B.D., Pehlivan E., 2011, Social spending: Managing the social media mix, Business Horizons, vol. 54, issue 3, May-June, s. 275-282.

Whiting A., Williams D., 2013, Why people use social media: a uses and gratifications approach, Qualitative Market Research: An International Journal, vol. 16, issue 4, s. 362-369.

Witten I.H., Frank E., 2000, Data Mining. Practical Machine Learning Tools and Techniques, Morgan Kaufmann, New York. 